С. Г. Божко ${ }^{1}$, І. А. Шевченко ${ }^{2}$, О. В. Печериця², А. М. Сингаївський ${ }^{2}$

${ }^{1}$ Державна інспекція ядерного регулювання України, м. Київ, Україна

22Державний науково-технічний центр з ядерної та радіаційної безпеки, м. Київ, Україна

\section{Управління знаннями,} робочими процесами

та електронним

документообігом у системі Держатомрегулювання. Підготовка платформи, розгортаннята впровадження Порталу знань

Стаття продовжує розпочатий упопередньомуномеріжурналуцикл публікацій з проблематики створення Порталу знань у галузі безпеки використання ядерної енергії. В ній аналізуються перспективи розвитку інформаційних технологій на 2016-2020 роки у частині, що стосується впровадження Порталу знань, розробка методики вибору платформи портального рішення, Концепції Порталу знань, підготовки платформи, розгортання та впровадження Порталу знань у дослідну експлуатацію.

Ключов і слова: політика інформатизації, управління корпоративним контентом, управління знаннями, портал знань, система електронного документообігу, тенденції розвитку інформаційних технологій, концепція порталу знань, впровадження портального рішення.

\section{С. Г. Божко, И. А. Шевченко, А. В. Печерица, А. Н. Сынгаевский}

Управление знаниями, рабочими процессами и электронным документооборотом в системе Госатомрегулирования. Подготовка платформы, развертывание и внедрение Портала знаний

Статья продолжает начатый в предыдущем номере журнала цикл публикаций по проблематике создания Портала знаний в области безопасности использования ядерной энергии. В ней анализируются перспективы развития информационных технологий на 2016-2020 годы в касающейся внедрения Портала знаний части, разработка методики выбора платформы портального решения, Концепции Портала знаний, подготовки платформы, развертывание и внедрение Портала знаний в опытную эксплуатацию.

Ключевые слова: политика информатизации, управление корпоративным контентом, управление знаниями, портал знаний, система электронного документооборота, тенденции развития информационных технологий, концепция портала знаний, внедрение портального решения.

() С. Г. Божко, І. А. Шевченко, О. В. Печериця, А. М. Сингаївський, 2016
П ершочергові кроки, необхідні для прийняття обгрунтованого рішення щодо доцільності впровадження системи управління знаннями, робочими процесами та електронним документообігом (далі - Порталу знань) у сфері безпеки використання ядерної енергії, та методичні підходи, засновані на практичному досвіді Держатомрегулювання і ДНТЦ ЯРБ, розглянуто у першій публікації з циклу статей за даною темою, надрукованій у № 2(70).2016 журналу «Ядерна та радіаційна безпека», с. 3-8.

Подальші передпроектні заходи державного органу, органу місцевого самоврядування, підприємства, установи та організації незалежно від форм власності (далі Установи) передбачають розробку пакету аналітичних, технічних та техніко-економічних документів. При цьому рекомендується враховувати результати аналізу світових тенденцій розвитку інформаційних технологій, аудиту стану інформаційно-телекомунікаційної системи (далі - ІІТC) Установи, деталізованої стратегії розвитку ІтТС Установи (далі - Стратегіï), концепції Порталу знань (далі - Концепції) та ескізного рішення.

Результати розгляду та погодження науково-технічною радою Установи Концепції та архітектури Порталу є підставою для підготовки Технічного завдання (далі - Т3) на розробку Порталу знань, формування планів-графіків закупівлі апаратних і програмних засобів, розробки й впровадження портального рішення та системи забезпечення інформаційної безпеки.

Робоче значення терміну «Nuclear Knowlage Management» (пропонуємо в якості перекладу - «управління знаннями в сфері атомної енергетики») вперше було введено в документі МАГАТЕ «Управління знаннями для експлуатуючих організацій атомної промисловості» [1] як комплексний, системний підхід до ідентифікації, отримання, перетворення, розвитку, поширення, використання, обміну та збереження знань.

На нашу думку, вказані напрями управління знаннями мають бути доповнені засобами забезпечення інформаційної безпеки, а саме - засобами забезпечення цілісності, доступності та керованого оприлюднення знань.

Крім того, беручи до уваги темпи розвитку засобів автоматизації, систем штучного інтелекту, кібернетичних загроз, цілком обгрунтованою є актуалізація таких технологічних викликів, як забезпечення синергії систем управління знаннями, систем кібернетичної безпеки ІІТС, систем фізичного захисту та автоматизованих керуючих систем. Вказані аспекти формуються об'єктивними вимогами 4-ї промислової революції [2], а здатність Установи відповідати прикладному контексту цих вимог визначатиме її ефективність.

Таким чином, базовим елементом створення Порталу знань $€$ розуміння світових тенденцій розвитку інформаційних технологій та визначення основних напрямів переформатування İТC Установи для забезпечення умов розвитку з мінімальними витратами матеріальних та людських ресурсів.

Після прийняття принципового управлінського рішення про доцільність створення Порталу знань та формування проектної групи подальші передпроектні та проектні заходи можуть бути побудовані у шість етапів. Планування процесу розробки відповідає ключовим етапам, визначеним ГОСТ 34.601-90 «Информационная технология. Комплекс стандартов на автоматизированные системы. Автоматизированные системы. Стадии создания», 3 певними доповненнями, що враховують, на нашу думку, сучасну специфіку. 
Рис. 1. Етапи підготовки проекту розробки Порталу знань

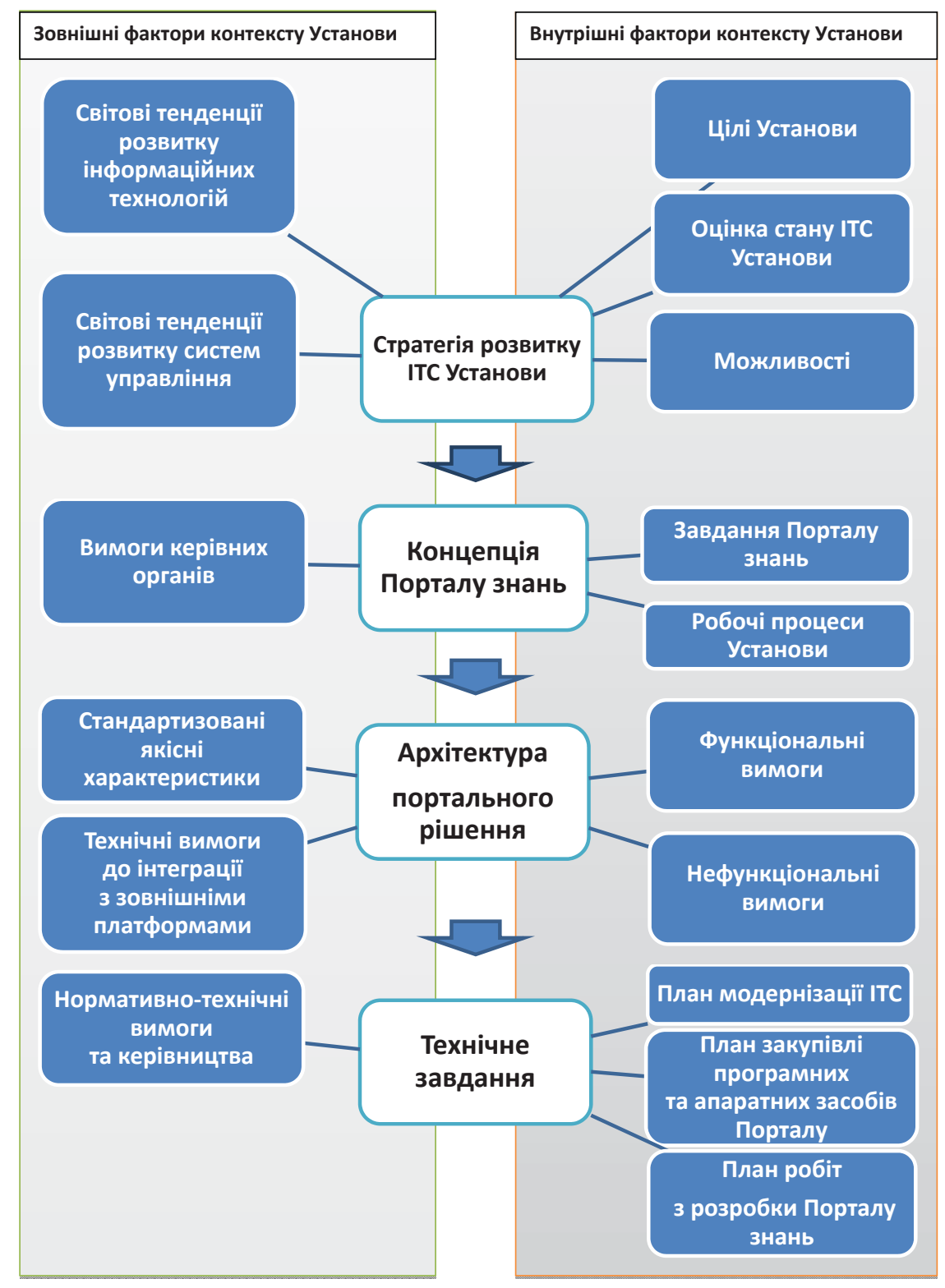

1-й eman: аналіз світових тенденцій розвитку інформаційних технологій; аудит стану ІІТС Установи; розробка деталізованої Стратегії розвитку ІТС Установи; розробка Концепції Порталу знань; розробка архітектури портального рішення (далі - Архітектура); оцінка ризиків (для великих та найбільш відповідальних проектів); погодження Концепції та Архітектури незалежними фахівцями та науково-технічної радою Установи;

2-й eman: розробка технічного завдання (відповідні плани можуть вводитися до ТЗ або розроблятися окремо); розробка плану-графіка закупівлі апаратних та програмних засобів; розробка плану-графіка модернізації ІІТС Установи; розробка плану-графіка робіт з розробки портального рішення; розробка плану-графіка робіт 3 впровадження системи забезпечення інформаційної безпеки; розгляд, доопрацювання та погодження технічного завдання (рис. 1);

3-й eman: модернізація ITC; забезпечення технічних умов розгортання програмного середовища Порталу знань;

4-й eman: розробка ескізного рішення; розробка технічного рішення; розробка комплекту документації; 5-ǔ eman: проведення навчання працівників Установи; пусконалагоджувальні роботи; попередні випробування; впровадження Порталу знань у дослідну експлуатацію; адаптація рішення;

6-й eman: проведення приймальних випробувань; впровадження в постійну експлуатацію; забезпечення технічної підтримки.

Ціль цієї статті - аналіз перспектив розвитку інформаційних технологій на 2016-2020 роки у частині, що стосується впровадження Порталу знань, розробка методики вибору платформи портального рішення, Концепції Порталу знань, підготовки платформи, розгортання та впровадження Порталу знань у дослідну експлуатацію.

Аналіз перспектив розвитку інформаційних технологій. Забезпечення ефективності Установи у довготерміновій перспективі економії витрат ресурсів на створення, підтримку та подальший розвиток Порталу знань потребує, в якості ключового фактора, врахування базових трендів розвитку інформаційних технологій, що перебувають на піку очікувань. 


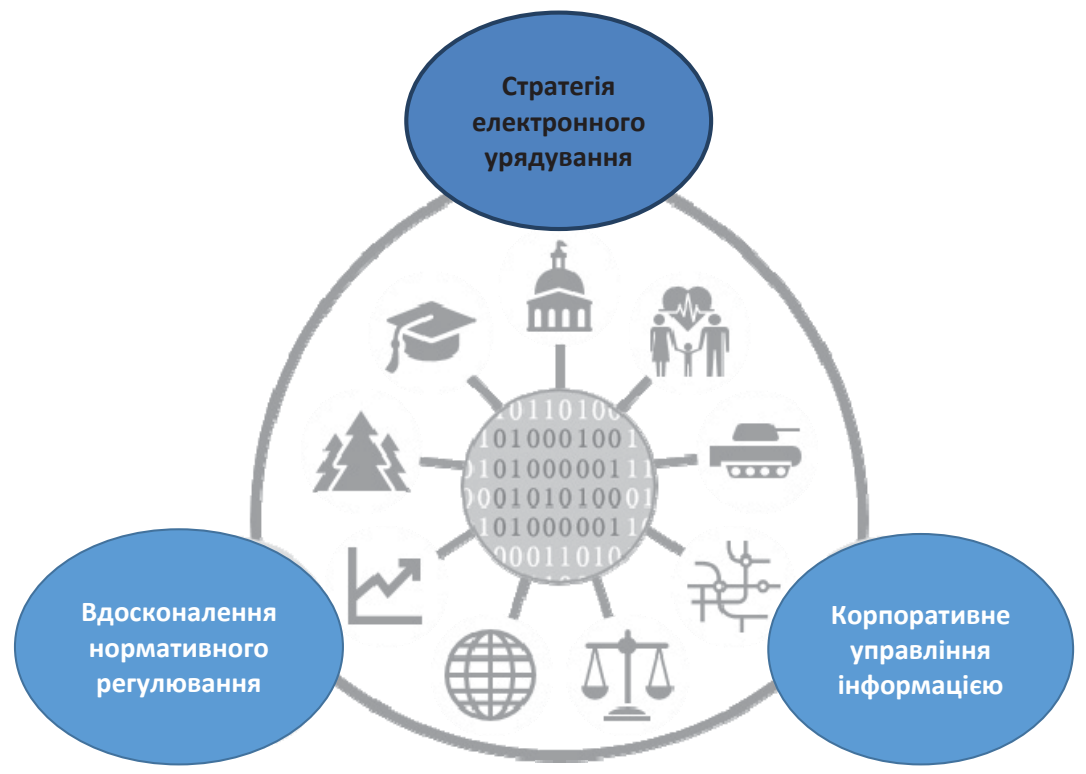

Рис. 2. Перехід до електронного урядування

На підставі проведеного фахівцями Держатомрегулювання та ДНТЦ ЯРБ аналізу, зокрема з урахуванням досліджень групи Gartner [3, 4], можна виділити такі тренди: розвиток електронного урядування, перехід сфери прийняття управлінських рішень і взаємодії між Установами та громадянами на рівень Їнтернет-комунікацій (рис. 2); створення систем автоматизації робочих місць працівників Установ, забезпечення колективної роботи та взаємодії, мобільності тощо;

використання систем аналізу великих масивів даних, систем аналізу даних у режимі реального часу;

швидке зростання темпів розвитку технологій, що поєднують елементи штучного інтелекту та машинного навчання;

швидкий розвиток технологій керування обладнанням через Їнтернет;

перехід від загального розширення хмарних сервісів до їх прикладного, галузевого застосування;

розвиток напрямків впровадження, аудиту, консультування та навчання в сфері технологій цифрового урядування.

Аналіз розвитку систем управління корпоративним контентом, з урахуванням дослідження аналітичної групи Gartner «Магічний квадрат для систем управління корпоративним контентом», опублікованого 21.10.2015, дозволяє зробити такі прогнозні висновки:

рішення щодо систем управління корпоративним контентом мають стійку тенденцію орієнтованості на «екосистеми», що об’єднують групи організацій;

керування контентом має тенденцію орієнтуватися на застосування гібридної архітектури з поступовим переходом на хмарні технології та технології обробки великих масивів даних.

Вибір платформи Порталу знань. Сукупність апаратних та програмних засобів, інтегрованих до ЇТС Установи, на яких будується Портал знань, формує платформу портального рішення.

Відповідно до рекомендацій фахівців GRS (Франк Діршов, Віталій Ївенін), Концепція Порталу знань, як правило, створюється на підставі Стратегії розвитку ІтТС Установи. Такий підхід є найприйнятнішим у разі, коли на підприємстві вже створена та функціонує розвинена İТC.
Якщо ж створення Порталу планується в застарілій або не упорядкованій ІтТ, Концепція Порталу знань може бути визначена як базовий документ, котрий встановлюватиме, зокрема, й вимоги до Стратегії розвитку ІІТС Установи в цілому. Саме в такий спосіб створювалася Концепція Порталу знань ДНТЦ ЯРБ.

У будь-якому разі, вибираючи платформу Порталу знань, підготовлюючи Стратегію розвитку ІІТС Установи, розробляючи Концепцію та Архітектуру, методологічно доцільно дотримуватися такої послідовності досліджень:

1. Аналіз світових тенденцій розвитку систем управління корпоративним контентом, даних авторитетних міжнародних рейтингових агенцій щодо оцінки якості та функціональності обраної платформи.

2. Аналіз відповідності програмних засобів вимогам законодавства та нормативних документів Держспецзв'язку України.

Зокрема, відповідно до «Переліку засобів технічного захисту інформації, дозволених для забезпечення технічного захисту державних інформаційних ресурсів та інформації, вимога щодо захисту якої встановлена законом», базові програмні продукти компаніï Microsoft визначені як такі, що відповідають вимогам НД ТЗІં (важливо також, щоб оновлені версії програмного забезпечення регулярно проходили атестацію).

3. Аналіз технічних можливостей обраної платформи Порталу знань щодо забезпечення функціональності та реалізації тих завдань, які планується вирішувати за його допомогою.

Загальні категорії якісних вимог [5], яким має відповідати програмне забезпечення, визначені стандартом ISO/IEC 9126: функціональність, надійність, практичність, ефективність, можливість супроводу. Більш деталізовану систему вимог визначає стандарт ISO/IEC 25010.

Крім функціональних вимог, доцільно брати до уваги можливості інтеграції та сумісності з платформами основних партерів, відповідність кращим загальносвітовим практикам, ефективність інтеграції апаратних та програмних засобів Порталу знань з іншими, вже існуючими елементами ІІТС Установи.

4. Аналіз поточного стану ЇТС Установи.

У рамках зазначеного аналізу вивчається наявність та різноманіття використовуваних апаратних засобів, серверного 


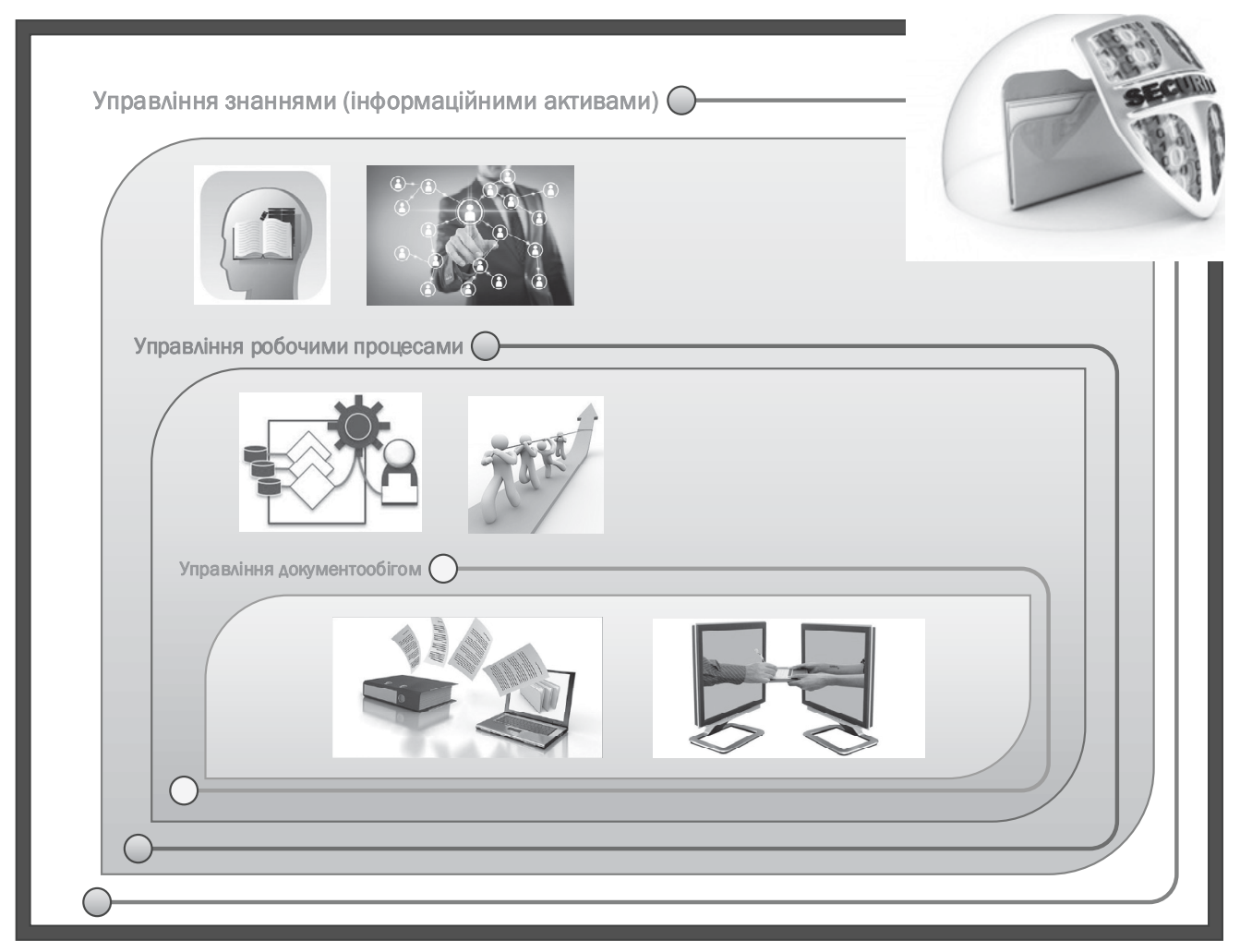

Рис. 3. Структура Порталу в системі процесного управління Установи програмного забезпечення, мережного обладнання, сіквелсерверів, задіяних автоматизованих інформаційних систем, розрахункових кодів, операційних та офісних систем користувачів. На підставі аналізу проводиться оцінка витрат та організаційних заходів з модернізації ІІТС Установи до рівня, достатнього для впровадження Порталу знань та забезпечення його подальшого розвитку.

5. Аналіз внутрішнього ринку щодо цінових пропозицій на апаратні та програмні засоби Порталу знань, наявності можливостей зниження фінансового навантаження.

У даному контексті доцільно дослідити:

наявність спеціальних пільгових програм постачання апаратного та програмного забезпечення в рамках політик ключових вендорів;

можливість отримання спеціальних адресних знижок;

можливість приєднання до маркетингових акцій постачальника;

можливість повного або часткового залучення фінансування за програмами міжнародного партнерства.

Наприклад, компанія Microsoft реалізує спеціальні пільгові програми ліцензування для державних установ, освітніх закладів та установ системи НАН України. Різноманітні міжнародні організації також можуть мати зацікавленість виступити донорами повного або часткового фінансування проектів інформатизації державного сектору та сектору безпеки.

6. Аналіз фінансових витрат на створення та підтримку експлуатації Порталу знань.

Оцінюючи вартість створення Порталу знань, крім очевидно необхідних витрат на закупівлі апаратних засобів та програмного забезпечення, доцільно враховувати також такі витрати:

на проведення робіт із системної інтеграції нового обладнання та програмних засобів до ЇТС Установи; підтримку постійної експлуатації Порталу знань (власними працівниками або сторонніми організаціями за договором аутсорсингу);

корегування або розширення обсягу завдань та функцій Порталу, внесення змін до дизайну та робочих процесів; масштабування платформи Порталу за обсягами інформації та кількістю користувачів;

підтримку актуальності та оновлення версій програмного забезпечення;

рекрутінг, за потреби, на ринку праці сертифікованих фахівців у достатній кількості й на конкурентних засадах; навчання та підвищення кваліфікації персоналу на авторизованих курсах.

7. Аналіз можливості формування власної проектної групи та команди розробників Порталу знань.

До команди розробників Порталу знань, за досвідом Держатомрегулювання та ДНТЦ ЯРБ, достатньо залучити три-чотири працівника з глибоким фаховим рівнем підготовки в галузі інформаційних технологій, а також дві-три особи із загальними професійними компетенціями. Крім того, до групи розробників у якості консультантів треба долучити представників відділів з організації діловодства, організації наукової діяльності, а також представників основних функціональних підрозділів Установи.

Взявши до уваги перелічені фактори зовнішньої та внутрішньої специфіки Держатомрегулювання та ДНТЦ ЯРБ, було прийняте рішення про використання в якості платформи Порталу знань комплексу програмних серверних продуктів Microsoft: SharePoint, SQL, Exchange, Skype-forBusiness, Power-BI.

Стратегією розвитку İTC закріплено першочергові вимоги:

відповідність апаратного та програмного забезпечення критеріям актуальності, якості та безпеки; 
уніфікованість програмного забезпечення за брендами та версійністю;

використання процесно орієнтованої архітектури

та гнучкого типу проектування [5];

побудова Порталу знань за хмарною технологією;

забезпечення інтегрованості Порталу знань з системою

електронної взаємодії органів виконавчої влади;

перенесення на платформу Порталу знань інтерфейсів автоматизованих інформаційних систем і баз даних Держатомрегулювання та ДНТЦ ЯРБ, засобів комунікації працівників, WEB-сайта, системи моніторингу господарського комплексу;

побудова схем робочих процесів відповідно до вимог системи управління якістю;

інтеграція робочих процесів Порталу знань ДНТЦ ЯРБ з робочими процесами Держатомрегулювання, НАН України, міжнародних партнерів, замовників та інших підприємств галузі;

забезпечення інформаційної безпеки Порталу знань у взаємоузгодженні з вимогами НД ТЗІ Держспецзв'язку, рекомендаціями МАГАТЕ та положеннями стандартів ISO27k.

Стратегічні вимоги детальніше розкриваються в Концепції Порталу знань через визначення завдань, структури та функцій Порталу, технічних вимог до платформи та системи забезпечення інформаційної безпеки. Концепція Порталу знань ДНТЦ ЯРБ складена за такою структурою: Вступна частина - Загальні положення Оцінка стану ЇТC - Стратегії розвитку - Завдання Порталу знань - Структура та функції Порталу знань - Технічні вимоги до платформи - Вимоги до системи забезпечення інформаційної безпеки - Очікувані результати.

Основною ідеєю побудови Архітектури портального рішення стала інкапсуляція завдань процесно орієнтованого менеджменту від управління електронним документообігом, через управління робочими процесами, до управління знаннями, коли кожна із зазначених сфер управління $є$ у зворотному порядку підмножиною попередньої (рис. 3).

Навчання групи розробників. Попереднє дослідження технічних можливостей платформи та напрацювання ескізного рішення Порталу знань відбувалося на базі платформи SharePoint Foundation 2013, починаючи з квітня 2015 року. Перший обмін досвідом щодо можливостей Порталу знань на базі SharePoint проведено в ході семінару, організованого GRS для фахівців ДНТЦ ЯРБ у Берліні в липні 2015 року.

Використання безоплатної версії серверного програмного забезпечення на передпроектному етапі дало змогу суттєво зменшити ризики витрат. Тільки після усвідомлення придатності обраної платформи, а також подальшого погодження Концепції та Архітектури Порталу знань фахівцями GRS, Держатомрегулювання та експертами науково-технічної ради ДНТЦ ЯРБ, було прийняте рішення про закупівлю програмного забезпечення.

Паралельно з підготовкою апаратно-програмної платформи відбувалося навчання команди розробників за двома напрямками на спеціалізованих курсах Microsoft: адміністрування сервера SharePoint; розробка застосунків SharePoint.

Окремо, за ініціативою команди розробників системи електронного документообігу Адміністрації Президента України (далі - СЕД АПУ) на базі SharePoint, проведено спеціальний тренінг з розгортання служб та застосунків СЕД АПУ, внесення адаптуючих змін, підтримки експлуатації.
Розгортання Порталу знань. За результатами оцінки стану ІТС ДНТЦ ЯРБ щодо її відповідності Стратегії розвитку та готовності до впровадження Порталу знань команда розробників дійшла висновку про необхідність повної перебудови мережі підприємства. Щоб забезпечити безперервність робочих процесів під час переходу до нового домену, розроблено та реалізовано технічний регламент з таким схематичним порядком операцій:

створення нового домену;

розгортання служби відкритих ключів РКI;

розгортання поштового сервера Exchange;

встановлення довірчих відносин між старим та новим доменами;

міграція облікових записів користувачів до нового домену (з одночасним переведенням на поштовий клі$є$ нт OutLook та уніфікацією операційних систем на рівні Windows 10);

підключення користувачів до нового поштового сервера (Exchange) з підтримкою старого поштового сервера (SendMail) протягом півроку;

міграція SQL-серверів та файлових серверів підприєм-

ства до нового домену;

розгортання поштового Web-сервера OWA;

розгортання SQL-сервера Порталу знань;

розгортання сервера та ферми SharePoint 2013 (за протоколом НТТР);

налаштування служб SharePoint 2013;

розгортання офісного Web-сервера OWA;

створення та налаштування сайтових колекцій корис-

тувачів та структурних підрозділів;

створення та налаштування сайтових колекцій функціональних розділів Порталу знань та робочих процесів

за напрямками діяльності;

міграція з SharePoint 2013 до SharePoint 2016;

перехід на використання протоколу HTTPS;

розгортання сервера Skype-for-Business;

деактивація старого домену;

розгортання СЕД АПУ (за технічним регламентом розробника);

налаштування засобів друку та сканування, формуван-

ня штрих-кодів, введення оцифрованих документів до СЕД; проведення пусконалагоджувальних робіт;

адаптація СЕД до вимог ДНТЦ ЯРБ;

проведення попередніх випробувань;

впровадження Порталу знань у дослідну експлуатацію.

Навчання користувачів проводилося в рамках п'яти тренінгів 3 формування навичок користування Порталом знань за такими напрямками:

загальна структура Порталу знань та особистих сайтів, робота в OneDrive, управління файлами та каталогами, управління доступом до власних інформаційних активів;

інструменти управління версійністю документів, колективна робота, користування каналом новин, блогом;

функціонал сторінок структурних підрозділів та сторінок загального користування, управління задачами, календарями, управління доступом до інформаційних активів підрозділу;

загальна структура системи електронного документообігу, введення документа в СЕД, етапи реєстрації вхідного документа, підготовки резолюції, погодження резолюції, делегування виконання, створення маршруту опрацювання документа;

створення вихідного документа, етапи створення маршруту опрацювання документа, вичитування, узгодження, 
підписання електронним підписом, реєстрація вихідного документа.

3 метою забезпечення постійної комунікації між користувачами та розробниками Порталу знань, у кожному структурному підрозділі ДНТЦ ЯРБ було призначено відповідального працівника 3 надання консультаційної підтримки користувачів на рівні відділу або лабораторії. у зворотному напрямку зазначені працівники надають команді розробників інформацію про виявлені недоліки та побажання користувачів щодо вдосконалення системи.

Фактично 3 липня 2016 року Портал працює в ДНТЦ ЯРБ у режимі дослідної експлуатації. Згідно з рішенням колегії Держатомрегулювання від 26.05.2016 проводяться роботи з підготовки ІІТС Держатомрегулювання до впровадження СЕД. У подальших публікаціях більш поглиблено розглядатимуться питання виконання робіт зі створення та кастомізації застосунків SharePoint, узагальнюватиметься досвід дослідної експлуатації та забезпечення експлуатаційної підтримки.

\section{Висновки}

Планування процесу розробки Порталу знань найбільш ефективно може бути забезпечене на основі модернізованої моделі, що доповнює вимоги ГОСТ 34.601-90 «Информационная технология. Комплекс стандартов на автоматизированные системы. Автоматизированные системы. Стадии создания», 3 урахуванням сучасної специфіки.

У процесі побудови Стратегії розвитку ЇТС Установи та розробки Концепції Порталу знань доцільно брати до уваги запропоновані в статті узагальнені аналітичні висновки щодо тенденцій розвитку інформаційних технологій; користуватися запропонованим методологічним підходом до вибору платформи Порталу знань; спиратися на процесно орієнтовану систему менеджменту та відповідно будувати Архітектуру Порталу за схемою послідовної інкапсуляції систем управління електронним документообігом, робочими процесами та знаннями. Розгортання Порталу знань найбільш ефективно можна забезпечити відповідно до запропонованого схематичного регламенту.

Наступна публікація буде присвячена проблематиці створення системи забезпечення інформаційної безпеки Установи.

\section{Список використаної літератури}

1. Knowledge Management for Nuclear Industry Operating Organizations. - Vienna : International Atomic Energy Agency, October 2006. - (IAEA TECDOC Series No.1510).

2. Schwab Klaus (2015), «The Fourth Industrial Revolution. What It Means and How to Respond», available at: https://www.foreignaffairs. com/articles/2015-12-12/fourth-industrial-revolution

3. Betsy Burton, David A. Willis, «Gartner's Hype Cycles for 2015: Five Megatrends Shift the Computing Landscape», available at: https:// www.gartner.com/doc/3111522

4. Jeff Vining, Rick Howard, «Transitioning to Digital Government Primer for 2016», available at: https://www.gartner.com/doc/3186620

5. Эспозито Д., Сальтарелло А. Microsoft.NET: архитектура корпоративных приложений. - К. : Изд. дом «Вильямс», 2016. $432 \mathrm{c}$

\section{References}

1. Knowledge Management for Nuclear Industry Operating Organizations, Vienna, International Atomic Energy Agency, October 2006, IAEA TECDOC Series No. 1510.

2. Schwab Klaus (2015), "The Fourth Industrial Revolution. What It Means and How to Respond", available at: https://www.foreignaffairs.com/articles/2015-12-12/fourth-industrial-revolution

3. Betsy Burton, David A. Willis, "Gartner's Hype Cycles for 2015: Five Megatrends Shift the Computing Landscape", available at: https:// www.gartner.com/doc/3111522

4. Jeff Vining, Rick Howard, "Transitioning to Digital Government Primer for 2016", available at: https://www.gartner.com/doc/3186620

5. Espozito, D., Saltarello, A. (2016), "Microsoft.NET: Architecture of Corporate Applications" [Microsoft.NET: arkhitektura korporativnykh prilozhenii], Kyiv, Williams Publishing House, 432 p. (Rus) 